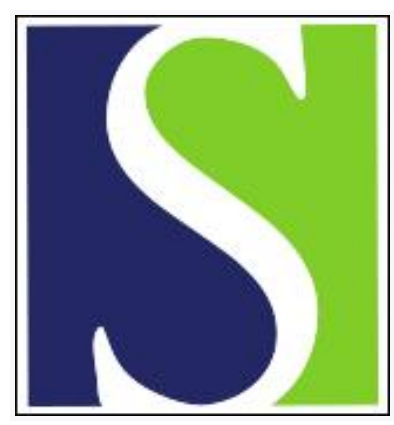

Scand J Work Environ Health 2008;34(2):83-95

https://doi.org/10.5271/sjweh.1222

Published online: 12 May 2008, Issue date: 31 Apr 2008

Worklife expectancies of fixed-term Finnish employees in 1997-2006

by Nurminen $M$

Affiliation: Finnish Institute of Occupational Health, Topeliuksenkatu 41 a A, FI-00250 Helsinki, Finland. markku.nurminen@ttl.fi

Refers to the following texts of the Journal: 2001;27(6):365-372

2005;31(3):169-178 2004;30(5):339-349 2001;27(6):361-364

The following articles refer to this text: SJWEH Supplements 2009;(7):41-47; 2019;45(1):73-81

Key terms: employee; employment contract; Finland; fixed-term employment; labor force statistics; worklife expectancy; workplace relations

This article in PubMed: www.ncbi.nlm.nih.gov/pubmed/18470440

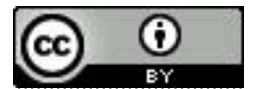




\title{
Worklife expectancies of fixed-term Finnish employees in 1997-2006
}

\author{
by Markku Nurminen, $P h D^{1}$
}

\begin{abstract}
Nurminen M. Worklife expectancies of fixed-term Finnish employees in 1997-2006. Scand J Work Environ Health. 2008;34(2):83-95.
\end{abstract}

Objectives Fixed-term employment is prevalent in the Finnish labor force. This form of employment contract is marked by fragmentary work periods, demands for flexibility in workhours, and concern for multiple insecurities. A nonpermanent employee may also incur adverse health consequences. Yet there exist no exact statistics on the duration of fixed-term employment. This paper estimated the future duration of the time that a Finn is expected to be engaged in irregular work.

Methods Multistate regression modeling and stochastic analysis were applied to aggregated data from surveys conducted among the labor force by Statistics Finland in 1997-2006.

Results In 2006, a Finnish male was expected to work a total of 3.8 years in fixed-term employment, combined over consecutive or separate time spans; this time amounts to $8 \%$ of his remaining work career from entry into the work force until final retirement. For a woman the expectancy was greater, 6.5 years or $13 \%$. For the age interval 20-29 years, the total was $16 \%$ for men and $23 \%$ for women.

Conclusions The type and duration of employment is influenced by security factors and economic cycles, both of which affect men and women differently. Over the past decade, fixed-term employment increased consistently in the female labor contingent, and it was more pronounced during economic slowdowns. This labor market development calls for standards for flexibility and guarantees for security in the fragmented future worklives of fixed-term employees.

Key terms employment contract; labor force statistics; workplace relations.

\begin{abstract}
Australian Workplace Agreements, which give the vertebra to the Federal Government's Work Choices legislation, have captured the public attention and imagination. They have even been deemed a subject worthy of television drama-an episode of the series McLeod's Daughters featured Patrick the mechanic being pressured to sign an AWA by an unscrupulous boss. "It's not actually your choice," Phil the boss told his employee. "You either sign this contract or I have to employ someone else ... it's either my way or ..." "I'll take the highway," Patrick replied, and out he walked.
\end{abstract}

-An extract from an article entitled Enslaver or liberator? AWAs conundrum by Jacqueline Maley in The Sydney Morning Herald May 21, 2007

Over the past decade or so, different new forms of employment relationships have emerged and remained a part of global change in the labor market (1). The regular form of employment contract, that is, one that is permanent (or ongoing), is increasingly being replaced by a contract signed for a fixed-term (often with several intermittent jobs), for a trial period, or for carrying out certain tasks. This development has partially led to what can be characterized as a "center-outskirts" structure of the labor force, in which the center comprises employees with permanent wage jobs, while the outskirts consist of workers with irregular, often unstable and insecure work arrangements. There are, in fact, several dimensions of insecurity, such as income insecurity and job insecurity (2). The new situation means fragmented futures for nonpermanent workers and challenges for the employers in organizing industrial relations (3). This is also the case in Finland, where fixed-term contracts and agency hiring are today broadly used. Frequently, the only route into employment is via the fixed-term, or casual pathway. Problems that arise from fixed-term employment confront both employees and employers. Financial instability, loose commitment to work, and uncertainty of worklife progress are among the current common concerns. An overview of the way that fixedterm employment is nowadays arranged in Finland can be found in an earlier publication (4), whereas, in my

1 Finnish Institute of Occupational Health, Work and Society Team, Helsinki, Finland.

Correspondence to: Dr Markku Nurminen, Finnish Institute of Occupational Health, Topeliuksenkatu 41 a A, FI-00250 Helsinki, Finland. [E-mail: markku.nurminen@ttl.fi] 
current paper, I am particularly interested in the estimation of the worklife expectancies of Finnish fixed-term employees.

\section{Duration of fixed-term employment}

The notion of worklife expectancy is the future duration that a person is expected to spend in employment, or the remaining number of years in a worker's career until he or she finally leaves the labor force. Note that this statistic is not, as sometimes assumed, the number of years until the person retires (turns 65 years of age or whatever the mandatory or voluntary age of retirement might be). The latter assumption is incorrect for the following two basic reasons: (i) an average worker has breaks in employment (withdrawals and re-entries) before his or her final retirement and (ii) the expected durations of worklife expectancy are estimated from occupancy probabilities for the employment states that form a probability distribution of the defined state space and compete with each other (compare with competing causes of death). These reasons naturally explain why the expectancies combined for people working under either of the two main types of employment contract, permanent or fixed-term, are shorter than the total duration of active worklife. In addition, there is the third type of employment, which consists of self-employment (including employers), which represents a distinct class of the employed labor force. Moreover, there are the unemployed who belong to the (gainfully inactive) labor force, as well as pupils (starting from 15 years of age) and students (until their late 20s), who are occasionally "swinging" between studies and employment but are not counted in the labor force. My comparative analysis primarily focuses on the relative duration of worklife in the first two primary employment contract states.

Information on the duration of the stay in fixed-term employment is generally lacking, and still less is known about workhours (frequently overtime) in this type of temporary employment. From the Finnish perspective, the situation is far more satisfactory in that the Labour Force Survey of Statistics Finland provides a continuous time series from 1997 on. In 1998, the longitudinal data file was revised in order for it to agree with the International Labour Organization's definition of laborforce participation. The database describes, among other things, the demographic and socioeconomic structure of the employed population by gender, age, education, and occupation, as well as the sector and permanency of employment. Based on these register and interview data, a comprehensive investigation provided detailed information on the prevalence of fixed-term employment relationships and knowledge of the changes that took place in Finland in the 1990s (5). In the past decade, 1997-2006, the prevalence of fixed-term work was stable, in 2006 at $16 \%$ (20\% for women and $13 \%$ for men). According to a survey of Finns' quality of life (6), the average length of time period in the same job was 10 years. In Finland, the probability of job change in fixed-term employment was as high as $76 \%$, whereas for permanent work it was only $31 \%$. It appears, however, that quantitative data on the permanency or duration of fixed-term employment has been neither extracted from administrative registers nor estimated.

\section{Previous demographic studies and the present analysis}

Previously, worklife expectancies have been estimated for aging municipal workers as a function of work (dis)ability $(7,8)$ and for the total Finnish population for different work or health states (9). As a result of these studies, new information was produced that can be utilized to promote measures or introduce incentives to prompt or entice Finnish people to continue working longer. In this paper, I present quantitative estimates of the duration that Finnish employees are expected to be engaged in fixed-term jobs, with a comparison to the time in permanent posts. The statistical problem is the modeling and estimation of probabilities of being occupied in these contract states as a function of age and year, separately for men and women, and taking into account the economic volatility of the time series. I close with a discussion of the socioeconomic implications of fixed-term employment in Finland.

\section{Study population and methods}

The sizes of the Finnish employed population for the most recent available and relevant years, 1997-2006, by gender and single-year age groups from 15 to 64 years were extracted from the statistical yearbooks published by Statistics Finland. For these years the demographic data by type of employment contract were complete. Existing data from some previous years were excluded to avoid interpolation. The 10 -year period is sufficiently long for the estimation of the probabilities of employment and heath status; moreover the recession effect in the early 1990s could be ignored. Estimates of the numbers of gainfully active persons by type of employment were based on the monthly surveys conducted among the labor force by Statistics Finland. In these surveys, fixedterm employees were counted as those who happened to be working in such jobs during the week of investigation. The numbers of annual deaths are the actual counts provided by Statistics Finland.

In all, the data consisted of a four-dimensional array of 3200 frequencies indexed by gender, age, calendar year, employment, and civil or vital status. 
The work history was regarded as a random process that evolves with age through various states before termination into retirement or death. My interest focused on the three transient index ("alive") states "permanent employees" (employed on a permanent or ongoing basis), "fixed-term employees" (employed on a fixed-term contract), and "other alive" (obtained by subtracting the number of those alive in the two former states from the size of the total population). The employed population was analyzed using the "permanent employees" versus "fixed-term employees" dichotomy, excluding self-employed persons (owner managers and unpaid family members). The (predominantly young) persons who could not state their employment arrangement constituted only approximately $0.1 \%$ of the employed, and they were discarded in the analysis. The complementary "other alive" group included, in addition to self-employed and unemployed persons (inactive labor force), those who were not in the labor force (students and persons on pensions due to disability or old age). In principle, one could partition the third "other alive" group into subpopulations. Unfortunately, this approach was not realistic because of the ensuing unmanageably large number of parameters in the regression model. The absorbing state, "death", labeled state 4 , was taken as the reference state.

A multinomial model was assumed for estimating the occupancy or "marginal" probabilities (that form a probability distribution at a given age) of being in any of the four mutually exclusive states. It was further assumed that the usual life-table assumption holds, that is, people in the same (age-year) cohort with the same initial evolve state stochastically in an independent and identical course as far as transitions between the states are concerned. Hence worklife expectancies are also "marginal" in the sense that we know only that initially people are alive (state 1,2, or 3) but not the distribution of their commencing state of employment or the activity of workforce participation.

Of pivotal importance are the occupancy probabilities, written $p_{j}(z, x)$, that a person, conditional on having reached age $z$, that is, 15 years or greater, is in state $j$ at a subsequent age $x>z$. In the present application, $j=1$, 2, 3, 4 indexes the exhaustive states $(1=$ "permanently employed", 2 = "employed for a fixed-term", 3 = "other alive", and $4=$ "dead"). The expected future occupation time of state $j$ at age $\mathrm{z}$ takes on the following form (9, equation 4 , page 579 ):

$$
e_{j}(z)=\int_{z}^{w} p_{j}(\mathrm{x} \mid z) d x,
$$

equation 1

where the maximum age $w$ before retirement (due to disability or old age) or until death, whichever comes first; here it is assumed that $w=64$ (ie, retirement at age
65 years). Aggregated data from which the occupancy probabilities can be estimated, on the assumption of a multinomial distribution model for the aggregated data, were available at ages $x=15, \ldots, 64$. The elegance of this simple mathematical formula lies in that, because the marginal probability $p_{j}$ assumes a value between 0 and 1 in any age differential $d x$-, the definite integral convolutes the $p_{j}$ into the respective expectation for state $j$. The $e_{j}$ s yield the expectations of interest, with $\hat{e}_{1}$ donating an estimate of the worklife expectancy. This integral can be evaluated using a discrete time approximation, but a real-valued function integrate was applied, as implemented in the S-PLUS system (10). Note that these quantities are conditional only in the sense that they depend only on the fact that a person is alive at the age of 15 years (7), and they should be distinguished from worklife expectancies conditional on knowledge of the initial state [compare with the work of Nurminen et al (8), in which an underlying inhomogeneous discretetime Markov chain was assumed]. The probabilities were estimated with the use of a multistate logistic regression. Advantage was taken of the fact that official statistics are almost always given in terms of large numbers, even for age strata. Standard errors of the parameter estimates, which can be determined with the delta method, were negligible. Practically all of the tested differences between the subgroups will be statistically significant.

The preceding arguments apply to estimating worklife survival surfaces and expectancies as functions of age for a given year. However, data were available for the 10-year period 1997 to 2006, and clearly variation with year was also of interest. It was therefore natural to formulate the vector of log ratios as a function of both age $x$ and year $t$. In an exploratory analysis, it emerged that the logarithm of the frequency of fixed-term employees can be represented by a multivariate model that has polynomial regression terms in time ( $x$ and $t)$. In addition, a satisfactory model contained a term for the annual change in the volume of the gross domestic product (GDP) to account for economic cycles and, especially, the recession effects in around 2002. The most parsimonious model (with 3 alive states) involved $3 \times 9=27$ parameters.

The analysis followed the procedure detailed earlier by Nurminen et al (9) to construct a parametric form in $t$ and $x$ for the logarithm of the probabilities for the index versus reference state ratios, $\log \left\{p_{j}(x, t) / p_{4}(x, t)\right\}, j$ $=1,2,3$. The model fits were depicted as surfaces over the rectangle $1997 \leq t \leq 2006,15 \leq x \leq 64$. The addition of quadratic and cubic terms of age and their interactions with the GDP introduced strong collinearities between the main effects and the interaction. Orthogonalization of the variates eliminated the collinearity (which centering of the variates alone did not achieve) and rendered the design matrix nonsingular. To conserve space, I have not included the explicit forms of the multistate models; 
these and the $\mathrm{S}$ language program code are available upon request.

\section{Results}

Throughout 1997-2006 the prevalence of fixed-term employment relationships among the women was markedly greater than among the men. There was a consistent increase in the number of female fixed-term workers over the decade, whereas, for the men, there was a slightly attenuating development. The observed relative frequencies for the permanent and fixed-term employment status for women and men are presented as surfaces in figure 1 . Numerical estimates for the integrated year- and agespecific worklife expectancies have been tabulated in the appendix. Table 1 in the appendix shows that, for example, the worklife expectancy of an "average" (or randomly chosen) 25 -year-old woman in the year 2000 was estimated to be $\hat{\mathrm{e}}_{1}^{F}(25,2006)=21.7$ in state $1, \hat{\mathrm{e}}_{2}^{F}(25$, $2006)=4.5$ in state 2 , and $\hat{\mathrm{e}}_{3}^{F}(25,2006)=13.2$ in state 3 . Thus the total expectancy for the three alive states was 39.4 years (and 0.6 years as deceased) until a person turns 63 (or would have had his or her 63rd birthday). In the defined state space, the $\hat{e}_{3}^{F}$ cannot, for modeling reasons, be broken down into two parts: one for those who belong to the workforce and the other for those who do not.
During the 10-year study period, there was a general increasing trend for the permanent employees' worklife expectancies for both genders. Figure 2 depicts the expectancies of the various employment states separately for women (A) and men (B) in 2006. For example, the worklife expectancy for an "average" (or randomly chosen) 15-year-old permanent female worker (table 1 in the appendix) was $\hat{\mathrm{e}}_{1}^{F}(15,1997)=20.6$ years, $\hat{\mathrm{e}}_{1}^{F}(15$, $2006)=23.6$ years (ie, $+14.7 \%$ ); and, for a 15 -year-old male worker (table 2 , in the appendix), it was $\hat{\mathrm{e}}_{1}^{M}(15$, $1997)=21.9$ years, $\hat{\mathrm{e}}_{1}^{M}(15,2006)=25.0$ years (ie, $+14.2 \%$ ). This result is an aftermath of the productivity growth in Finland, which accelerated at a brisk rate in the beginning of 2006, the GDP exceeding the preceding year's level by $6 \%$. The economic growth rate in 2006 was at the same top level as in 1997-1998 (figure 3). The exceptional extent and force of the growth led to a self-feeding cycle the like of which had been seen only a few times during the previous 35 years. The upswing was predicted to have an above-average duration, but the growth slowed down to $4.4 \%$ in 2007 , and it will decrease further to $3.2 \%$ in 2008 (11). Note incidentally that there was a consistent drop in the expectancies from 2005 to 2006 for both genders and at all ages among the permanently employed people. This finding may be the model-based anticipation of a downward turn in the economy, and it deserves to be followed in view of the looming slowdown (or recession) in 2008.

\section{Permanent}

Fixed-term

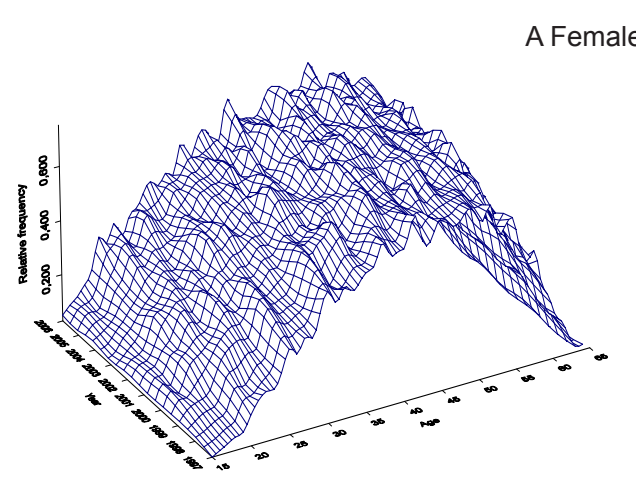

A Female employees
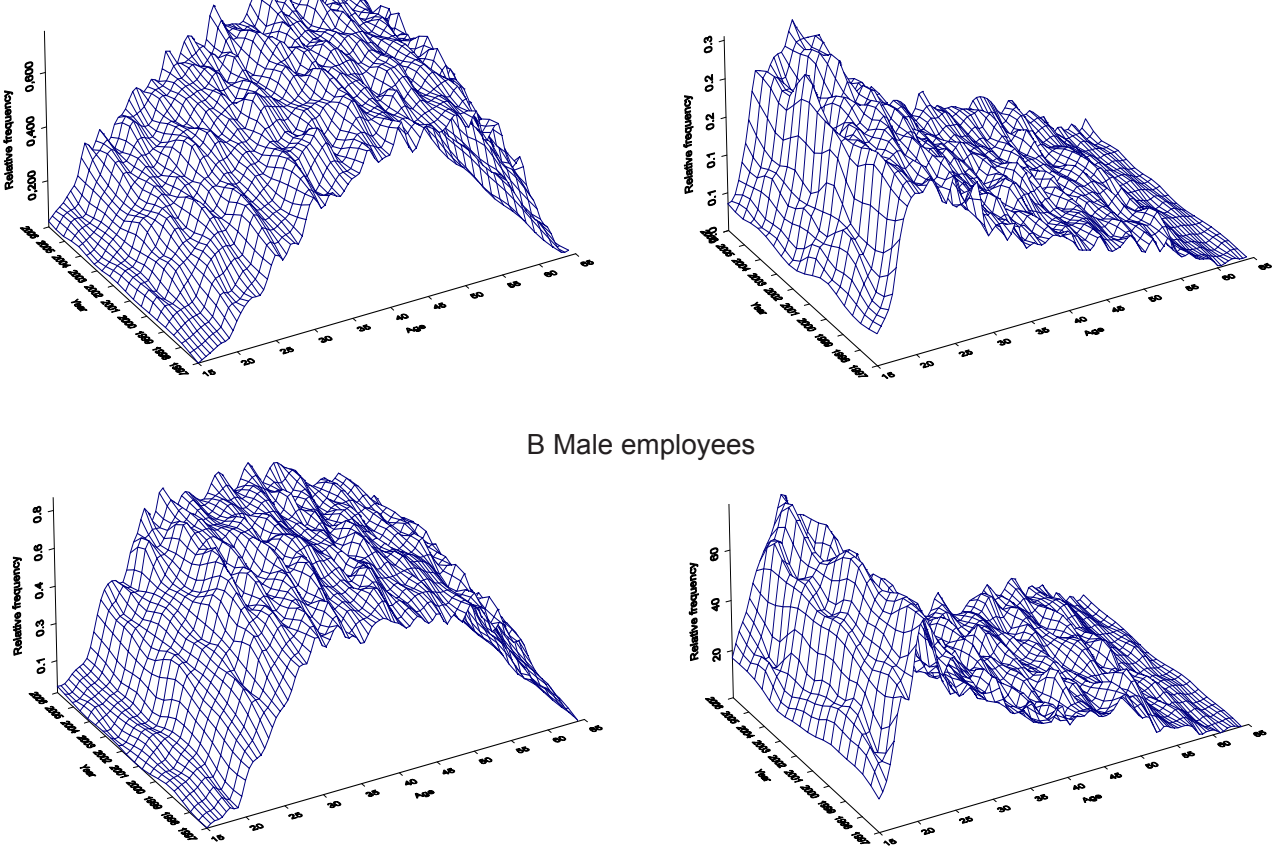

B Male employees

Figure 1. Observed relative frequencies of permanent and fixed-term Finnish female (A) and male (B) employees joined as a surface with age and year axes. 
A Female employees

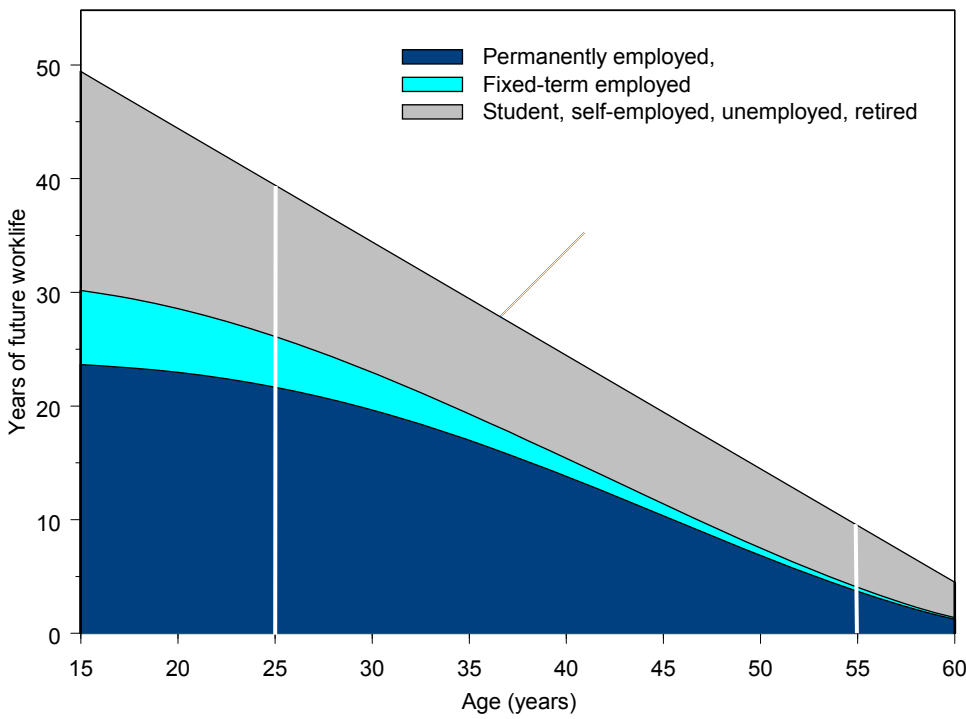

B Male employees

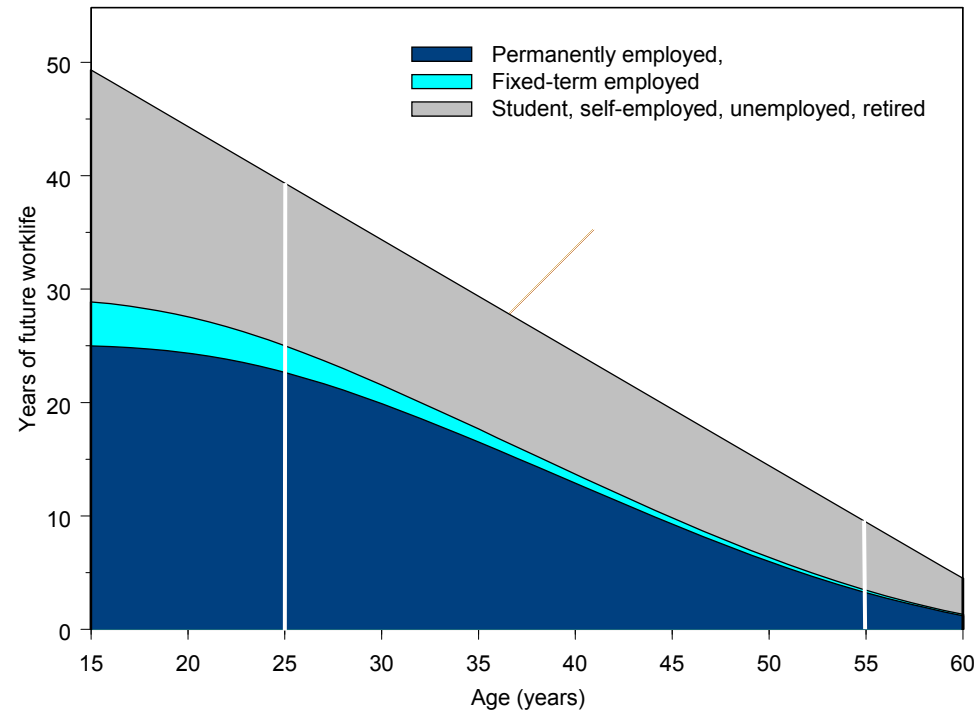

Figure 2. Expected number of years remaining in worklife spent in various employment and health states at different ages for Finnish women (A) and men (B) in 2006. Note the relatively large allocation of years for the "other alive" group (topmost segment) [eg, at the ages of 25 (due to students) and 55 (due to retirees) years].

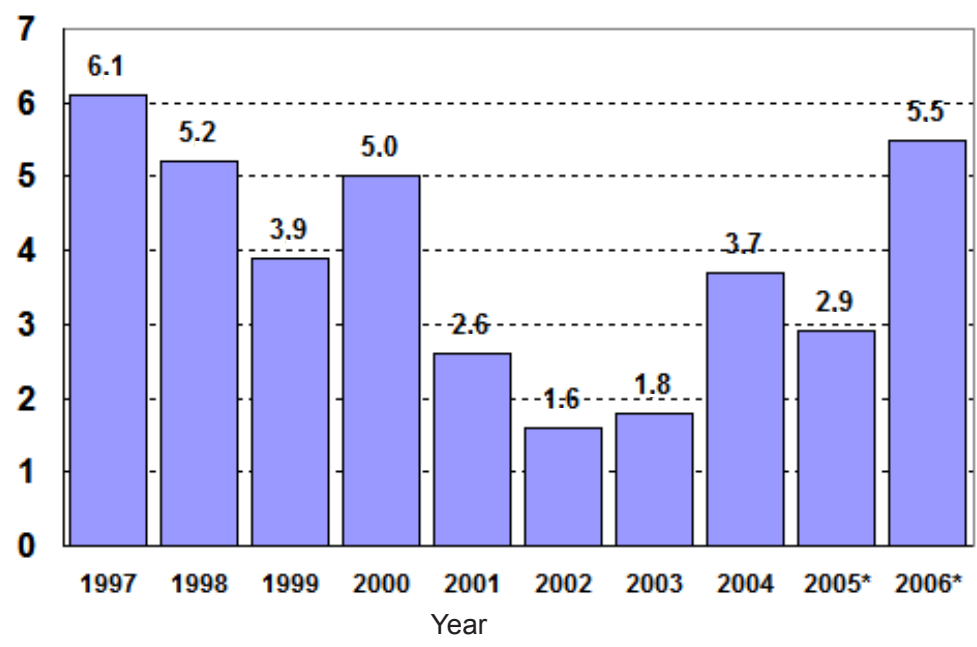

Figure 3. Annual percentage of change in the volume of the gross domestic product in 1997-2006. [Source: National Accounts 1997-2006, Statistics Finland] 
In the case of fixed-term employees, the changes in worklife expectancies (following the corresponding trends in prevalences) over the decade took different directions for the genders (figure 2). The band was markedly wider for women than for men over the entire age range. For example, the male versus female ratio $\hat{\mathrm{e}}_{2}^{F}(25,2006) / \hat{\mathrm{e}}_{2}^{M}(25,2006)=1.9$ and $\hat{\mathrm{e}}_{2}^{F}(55,2006) /$ $\hat{\mathrm{e}}_{2}^{M}(55,2006)=1.6$. The gender-specific overall trend rose annually for the female expectancies (table 1 , in the appendix): $\hat{\mathrm{e}}_{2}^{F}(15,1997)=5.8$ years, $\hat{\mathrm{e}}_{2}^{F}(25,2006)=$ 6.5 years (ie, $+13.0 \%$ ). By contrast, there was a slightly declining trend for the male expectancies (table 2, in the appendix $): \hat{\mathrm{e}}_{2}^{M}(15,1997)=4.0$ years, $\hat{\mathrm{e}}_{2}^{M}(15,2006)=$ 3.9 years (ie, $-4.2 \%$ ). These figures constituted $13 \%$ of the women's maximum careers until retirement, and $8 \%$ of the men's careers. The age trends show even higher proportions for the times worked in fixed-term jobs in the 10-year age interval 20-29 years (table 1, in the appendix); for example, in 2006, the difference in worklife expectancies was $\hat{\mathrm{e}}_{2}^{F}(20,2006)-\hat{\mathrm{e}}_{2}^{F}(30,2006)=5.6$ $-3.3=2.3$ years (ie, 23\%). For the men, the corresponding difference was smaller (table 2 , in the appendix): $\hat{e}$ ${ }_{2}^{M}(20,2006)-\hat{\mathrm{e}}_{2}^{M}(30,2006)=3.2-1.6=1.6$ years (ie, $16 \%)$. Thus the annual trends in fixed-term employment were substantially dissimilar for the genders.

An exceptional feature of these time series is that, during the economic recession in 2002-2003, there was a 5-6\% dip in the expectancies for fixed-term male employees. In stark contrast, the expectancies of their female compatriots increased by a compensating 8-9\% over these years. This discrepancy is clearly evident in the female versus male ratio of fixed-term employees during the economic slump around 2002 (figure 4). Even the local downturns in the volume of the GDP in 1999 and 2005 are discernible and, without time delay, are reflected in the gender ratio. Considering that the prevalences of both permanent and fixed-term employment stayed approximately at the same level over the

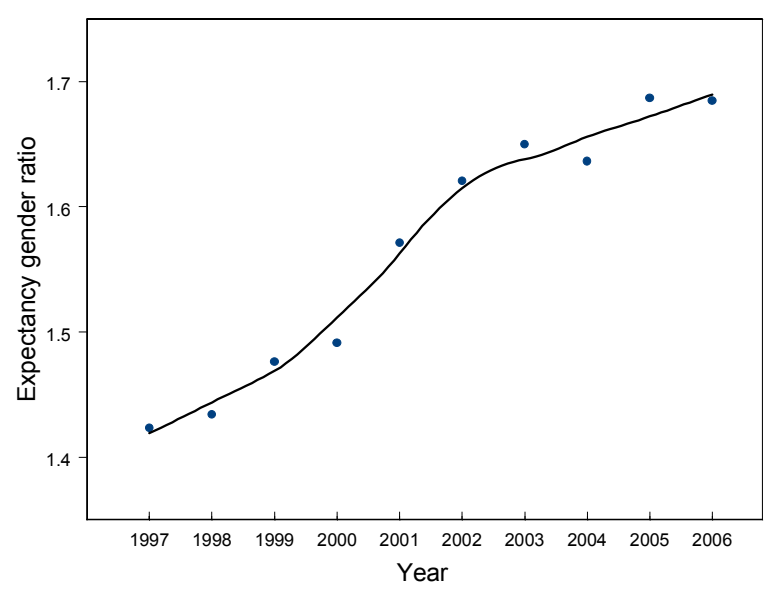

Figure 4. Annual trend (local linear regression fit) for fixed-term worklife expectancy in 1997-2006, gender ratio. decade 1997-2006 for both genders, the developments in the expectancies must, by and large, be regarded as a consequence of the economic cycles.

To counterbalance the general increasing trend among permanent employees, the estimated worklife expectancies for the "other alive" subpopulation $\left(\hat{\mathrm{e}}_{3}\right)$ declined by $16.4 \%$ among the women and by $12.5 \%$ among the men. The concomitant falling unemployment rate, by 5 percentage points for either gender (from $13.1 \%$ to $8.1 \%$ for women and from $12.4 \%$ to $7.5 \%$ for men) may have contributed to this development. Note the relatively large allocation of years for the "other alive" group, which is presumably due to the elongation of students' studies (eg, at the age of 25 years) and due to early retirement (eg, at the age of 55 years). [See figure 2.]

\section{Discussion}

\section{Expectancy and course of worklife}

Worklife expectancy (compare with life expectancy) is a summary measure of a population's state of employment and health (12). It is useful in a quantitative analysis, whereas the "worklife course" approach provides a basically qualitative perspective. The cross-sectional data published by Statistics Finland have not earlier been processed to the point that they could be used for estimating longitudinal processes. However, the life-course information may contribute to a socioeconomic policy debate on the reorganization of worktime arrangements to make allowance for private life. A report of the European Foundation for the Improvement of Living and Working Conditions addresses the subject of reorganizing time requirements in fixed-term and part-time work specifically from the life-course perspective (13). These two approaches are best seen as supplementary, rather than as competing, methodologies.

In this paper, worklife expectancy was the method of choice because of its advanced statistical qualities (14). Consider, for instance, the property of the largesample regression model used to estimate employment trends over time and across age groups of permanent and fixed-term workers, using information from crosssectional surveys of a cohort population to reconstruct relevant parts of the longitudinal work career. This novel approach is an alternative to the traditional route followed by demographers and other social scientists in the analysis of "increment-decrement" life tables (14). Population projection methodology, including probabilistic methods, has been used to analyze changes in the state of populations in spatiotemporal studies (eg, the transition model for period-cohort life-table data). Given aggregated data from sequential cross-sectional population surveys or from longitudinal follow-up studies, 
a multistate regression model can be used to estimate consistently marginal probabilities that a person is in a given work-health state (the case in point) or transition probabilities between the states, and thereby worklife expectancies. A comparative perspective of the life-table and regression analysis approaches can be found in an earlier publication (15).

While prevalence by type of employment gives a cross-section of the status distribution of the working population, expectancy is intrinsically an individual measure that projects the duration from a person's present age to the finish of his or her worklife. And, the closer an employee comes to retirement age, the more vital the information conveyed by the remaining worktime worklife expectancy. In my own case, $\hat{\mathrm{e}}_{1}^{M}$ (60, 2006) $=1.2$ years.

\section{Gender differences}

Gender imbalance constitutes a significant factor in fixed-term employment relationships (16). According to a recent Finnish survey of the labor market, temporary employment contracts among the highly educated are typically a problem for young women (17). The clustering of work with a fixed termination date among women in the family-forming age range suggests that employers may try to circumvent rules regarding a notice of the discontinuation of a contract and the expenses that derive from a family (more often maternity than paternity) leave by using temporary jobs. Not all employers seem to realize (or disregard) the fact that a temporary work contract cannot be left unrenewed or limited in duration because of pregnancy or family leave. However, for an individual fixed-term employee, it can be hard in his or her position to question the basis of the temporariness. According to a questionnaire study conducted in Finland by the Office of the Equality Ombudsman (18), the failure to renew a temporary employment contract is one of the most common problems of equality, and it can discriminate against women.

\section{Adverse health consequences}

A systematic search for studies of temporary employment and various health outcomes identified 27 studies (19). The evidence suggests that temporary workers have increased psychological morbidity and high employment instability when they are compared with permanent employees.

A Finnish study (20) examined self-reported health and recorded sickness absences of a cohort of 5650 fixed-term employees and substitutes in 10 hospitals. The perhaps unexpected findings were that contingent employees fared better in both respects than their permanent counterparts. The differences in self-rated health may be partly explained by differential selection out of the workforce for health reasons and differences in sickness absence by unequal thresholds of taking sick leave or working while ill. But no difference was found in the prevalence of diagnosed diseases and psychiatric morbidity between the compared groups.

Another Finnish questionnaire study of perceived morbidity in the labor market (21) found fewer fixedterm employees than permanent employees reporting work-related illnesses and symptoms. On the other hand, more work accidents were reported by fixed-term employees, who often change jobs and have to adjust to new work environments. The rate of work accidents diminished with the continuation of the work relationship (22), which is no doubt partly due to increasing years of experience.

It has been hypothesized that fixed-term employment can cause mental stress. When fixed-term or temporary work is perceived as an interim phase in worklife, it can be connected to finding longer term or permanent employment (23). It has been argued that fixed-term employment is always better than no work at all (24). The situation becomes stressful when fixed-term employment forms a trap of insecurity from which the only escape is unemployment (24). Studies have shown that the effects of insecurity are apparent in the lowered mental well-being of employees, for example, as signs of work dissatisfaction and work tiredness, as well as stress and psychosomatic symptoms $(25,26)$. A register linkage study of 65200 civil servants in 10 Finnish towns found that temporary employment is associated with antidepressant use among women and men and that this use is more pronounced when employment is unstable (27). The highest use was found among long-term unemployed persons who were in short-term government-subsidized temporary employment.

In addition to the psychosocial stress associated with the uncertainty of work continuation (28), temporary employment carried a 1.2 (women) to 1.6 (men) times higher risk of mortality, especially from alcohol-related causes and smoking-related cancer, compared with the risk among permanent employees in Finland (29). Moving from temporary to permanent employment was found to lower the risk of death significantly.

A Finnish epidemiologic study found that good health status seems to promote the chances for a fixedterm hospital employee to reach permanent employment (30). A recent Finnish study of initially fixed-term employees in the public sector provided evidence of health-related selection into employment trajectories and suggested that these trajectories carry different health risks (31). But, despite the adopted design, the direction of causation could still be the reverse, in other words, a case of people who became sicker during the follow-up period being less capable of having stable employment, 
rather than a case of people entering unstable employment tending to incur poorer health.

\section{Effect of economic factors on workplace relations}

The causes for fixed-term employment vary naturally according to the branch of economic activity. In the female-dominated municipal sector, the most important basis is temporary substitution. For example, teachers are hired only for a year of study or the workdays of a term. In the public sector, fragmentary funding is regarded the main cause. At universities, for example, teaching and research work is predominantly fixed-term. A significant part of fixed-term jobs is a result of projects carried out with outside funding that lasts a certain length of time. Many of these jobs are due to (mainly postgraduate) studies done in a work relationship. In the private sector, the temporariness of work is related to the project nature of the work assignment.

In times of economic growth, municipalities can more easily hire substitutes and other fixed-term employees, whereas in stricter times communities strive to save personnel expenses by laying off staff. Concrete evidence of this business-cycle phenomenon occurred during the economic recession in the early 1990s. The number of fixed-term employees decreased, especially in the public sector, which suffered from a very tight budget as a result of the deep recession and a lower tax income. Those who survived the slump-particularly people over 55 years of age-remained employed. After the recession, the number of fixed-term employees again increased due to a growing demand for services related to a structural change in the economy. Temporary employment started to affect also workers who had already accumulated long work experience. However, women entering the labor market from the mid-1990s on have experienced difficulties in stabilizing their careers in the long run (32). And a new economic downturn that reached its low around 2002 again temporarily increased the number of unemployed men.

\section{Expected status of the Finnish labor force}

The employed sector of the Finnish population is aging more rapidly than that of most other European countries, and this demographic development can entail serious social and economic implications for society in coming years (33). This outlook is due to the fact that the decrease in the labor supply will, in the near future, shake the financial base of an established market economy and thereby undermine the foundation of a welfare society (34). This dire forecast is made despite the good status of employment, which rises in parallel with the GDP. The sustainability of pension systems, intergeneration fiscal equity under the demographic gradation, and the consideration of medical expenditures and health care costs of future retirees remain among the current core of demographic and social policy issues that need to be addressed.

The possibilities to increase the supply of labor depend on current employees' postponing their retirement, but also on laborers coming from outside the Finnish workforce (2.4 million employed). Annually only 30000 foreigners work in Finland in fixed-term and other temporary jobs. Because of the acute labor shortage, in particular in the health care and service sectors in the Helsinki metropolitan area (35) and in seasonal jobs in Finnish Lapland (36), organized immigration to Finland is expected in increasing numbers in the future (37).

According to the economic forecast of the Ministry of Finance in Finland (11), the number of employed will increase by about 50000 people in 2007. This development means that the employment rate will rise to $70 \%$. Job creation has been particularly good in private services and construction. Labor supply will exceed the 2006 figure by 30000 . A forecast has also been made that the seasonally adjusted unemployment rate will still be below the 7\% mark at the end of 2007. While reducing unemployment and promoting migration are important ways to increase the workforce, other European studies suggest measures that would accomplish later retirement. For example, in the Netherlands, measures have been considered to encourage Dutch employers to raise older workers' participation in the workforce (38). These measures included part-time early retirement or prepaid pensioning, additional leave or increased holidays, prolonged career interruptions, age limits for irregular work, exemption from overtime work, flexible workhours, training programs, reductions of workloads, and ergonomic improvements. The challenge is to change the employers' attitude to not necessarily associate older workers with lower productivity and higher wage costs. There is a need for incentives to keep aging workers employed in order to meet or alleviate the replacement demand in the current tight situation within the labor market. The growing labor shortage, which is linked to the economic cycle, is becoming more structural in Finland as a result of ongoing demographic development. As the labor supply decreases, economic growth will have to be based on improved productivity.

The reduction of the labor force is not only the result of premature retirement. The problem is that increasing numbers of working-aged persons have completely stayed outside the labor market. The major shift in the probability of being employed seems to reflect a changed behavior among those under 30 years of age, no doubt partly due to increasing years of education (with studies extending until the late 20s). A prolonged absence from the labor market often makes the return to work more difficult. These employment breaks are 
reflected in worklife expectancies but not necessarily in average retirement ages.

Statistics Finland publishes data on the distribution of the number of employees doing full-time and parttime work, and the Ministry of Labour has compiled statistics on the duration of employment contracts, possibly combined from separate periods of work for the same or different employers. However, the duration of employment contracts has only been considered by dichotomizing it in terms of whether it lasts less or more than a year (5). However, thus far, there have been no quantitative estimates available on the expected duration of fixed-term employment in Finland, or, for that matter, in any other developed country. Instead, in this paper the actual worklife expectancies were estimated. Over the decade 1997-2006, the expectancies for fixed-term workers in their entire careers averaged 6 years for a woman and 4 years for a man. By comparison, under Hungarian law, the maximum duration of a fixed-term contract is 5 years (39). Yet, for many employees, the combined duration of fixed terms is years longer. The duration that Finnish workers spend in nonstandard employment relationships constitutes marked phases of their career, and, especially for people in their 20s, this length of time is significant. This situation calls for standards for flexibility and guarantees for security in the fragmented futures of fixed-term workers.

\section{Workplace relations and social segmentation}

Usually fixed-term contracts are regarded as more insecure than permanent ones. A permanent work relationship is often a significant rewarding factor for an employee (40). It creates security and possibilities to better plan one's personal economy. Persons employed in permanent jobs can also commit better to the tasks of a workplace. Persons with a fixed-term contract have to consider alternative plans more often, and they experience job insecurity. But a fixed-term worker can also feel relative security, provided that the economic outlook of the organization is such that it affirmatively promises continuation of the contract.

If an average employee is expected to be in a fixedterm contract for 5 years and to have a permanent position the rest of his or her career, the issue of whether a fixed-term contract is a problem (except possibly for gender differences) could be raised. Problems probably arise when there is a division between insiders and outsiders in the labor force. Open questions of the conditional form "What are the chances to remain in fixed employment contracts over one's career?" and "Do the opportunities of getting a permanent post (given that a person is still working under a fixed-term contract) increase or decrease as a worker ages over time?" were not posited in this study. [Mark well that the occupancy probabilities were assumed independently of the initial employment state, and transition probabilities were not estimated.] A possible answer can be sought from local Finnish circumstances.

A Finnish study questioned whether the increase in fixed-term employment leads to poor psychosocial work environments. The researchers' argument (41) was "The growth of temporary employment as such seems to have only limited potential to create new social divisions or to strengthen existing ones[;] in Finnish labor markets politics and policies do still matter in issues of working life [p 205]." In Finland, the basis for the growth of fixed-term employment differs greatly with regard to the structure of the labor force from that in the United Kingdom and in the United States. The researchers stressed that this expansion has not led to a significant division between better jobs for permanent employees and worse jobs for fixed-term employees. This relatively small segmentation of the labor market is (or has been) thus far due to special local Finnish conditions, such as the large public sector, the small size of establishments, high union participation, and an ethnically homogeneous population (42).

Still, there may exist a real risk in Finland of an economic division of labor into an "inner" and "outer" circle (43), namely, those whose positions in the labor market are permanent and financially well-founded (inner circle) and those in atypical employment with incidental income (outer circle). The latter subpopulation acts as a labor-force buffer to the inner circle, whose position thus becomes more secure. Although enterprises hire fixed-term employees as a result of demands for flexibility regarding labor availability and cost saving, the insecurity is stressful to the individual worker regardless of its reason. An interesting recent observation is that firms are interested in changing fixed-term contracts into permanent ones in view of the expected economic downturn and the following labor shortage. In addition, the Australian Bureau of Statistics Survey (44), on employment arrangements, found that a clear majority of fixed-term employees (72\%) expected that their contract would be renewed. This finding indicates that many fixed-term employees may have a longer tenure than their employment arrangement would suggest. It follows that fixed-term employment can be viewed either with a negative attitude or a positive attitude, depending on the individual worker's personal employment or life situation. Either way, the length of the work careers of fixed-term employees in Finland falls way short of those of employees in typical work relationships, the duration of employment varying greatly by gender and age.

\section{Concluding remarks}

The preceding discussion and the empirical results of this study stress the importance of the more cautious 
employment (rather than deployment) of fixed-term labor so as to enhance its longer term development and not undermine the growth of permanent employment [compare with the conclusions of Buchanen (45)]. For the social policy decision maker, the question is whether to actively influence the employment process or let it flow volatilely with economic market currents. Regulation with new labor legislation is one solution for controlling the situation. From the beginning of 2008, changes in Finnish legislation came in force that are aimed at reducing the number of unjustified fixed-term employment contracts and at converting them into permanent ones. Negligence to comply with the employment contract conditions will be punishable by law. Other suggestions on how to improve work standards are provided by reference to new practices and arrangements concerning, for example, professional training and improvement in parental leave, as well as to better meeting the demands of work versus compelling family commitments and the interests of private life.

\section{References}

1. Aronsson G. A new employment contract [editorial]. Scand J Work Environ Health. 2001;27(6):361-4.

2. Standing G. Beyond the new paternalism: basic security as equality. London: Verso; 2002.

3. Watson I, Buchanan J, Campbell I, Briggs C. Fragmented futures: new challenges in working life. Sydney: The Federation Press; 2003.

4. Nurminen M. Fixed-term employment: the Finnish way. J Occup Health Saf Aust NZ. 2007; 23(6):539-56.

5. Sutela H, Vänskä J, Notkola V. Pätkätyöt Suomessa 1990luvulla [Very short fixed-term jobs in Finland in the 1990s]. Helsinki: Statistics Finland; 2001. Työmarkkinat 1.

6. Lehto A-M, Sutela H. Threats and opportunities: findings of Finnish Quality of Work Life Surveys 1977-2003. Helsinki: Statistics Finland; 2005.

7. Nurminen MM, Heathcote CR, Davis BA. Estimating marginal cohort working life expectancies from sequential cross-sectional surveys. J Off Stat. 2004;20:495-517.

8. Nurminen MM, Heathcote CR, Davis BA. Estimating conditional working life expectancies from aggregate cohort data. Internet J Epidemiol [serial on the Internet; cited 2008 Jan 17]. 2004;1(2): [about 30 p]. Available from: http://www.ispub. com/ostia/index.php?xmlPrinter=true $\&$ xmlFilePath=journals/ ije/vol1n2/life.xml.

9. Nurminen MM, Heathcote CR, Davis BA, Pusa BD. Working life expectancies: the case of Finland 1980-2006. J R Stat Soc Ser A Stat Soc. 2005;168:567-81.

10. Venables WN, Ripley BD. Modern applied statistics with SPLUS. 4th edition. New York (NY): Springer; 2002.

11. Ministry of Finance (Economics Department Finland). Econ Bull [Internet]. 19 December 2007;(4) [cited 1 May 2008]. Available from: http://www.vm.fi/vm/en/04_publications_and_documents/01_publications/02_economic_surveys/ 20071219Econom/econbull407-b.pdf.

12. Nurminen M. Working population health metrics [review].
Scand J Work Environ Health. 2004;30(5):339-49.

13. Naegele G. A new organization of time over working life [Internet]. Luxembourg: European Foundation for the Improvement of Living and Working Conditions (EUROFOUND); 2003 [cited 1 May 2008]. 164 p. Available from: http://www. eurofound.europa.eu/publications/htmlfiles/ef0336.htm.

14. Wilson T, Rees P. Recent developments in population projection methodology: a review. Popul Space Place. 2005;11(5):337-60.

15. Nurminen M, Nurminen T. Multistate worklife expectancies [review]. Scand J Work Environ Health. 2005;31(3):169-78.

16. Sutela H. Fixed-term employment relationships and gender equality. In: Nätti J, Sutela H (editors). Gender equality in working life. Helsinki: Statistics Finland, Ministry of Social Affairs and Health; 1992. Labour Market, 22/1992.

17. AKAVA (The Confederation of Unions for Academic Professionals in Finland). Annual labour market survey 2004. Helsinki: AKAVA; 2004

18. Ministry of Social Affairs and Health. Annual report of the equity ombudsman 2001. Helsinki: Sosiaali- ja terveysministeriö; 2002. Equity Publications 4/2002.

19. Virtanen, M, Kivimäki, M, Joensuu, M, Virtanen, P, Elovainio, M, Vahtera, J. Temporary employment and health: a review. Int J Epidemiol. 2005,34(3):610-22.

20. Virtanen M, Kivimäki M, Elovainio M, Vahtera J, Cooper CL. Contingent employment, health and sickness absence. Scand J Work Environ Health. 2001;27(6):365-72.

21. Notkola V, Vänskä J. Määräaikaisten työntekijöiden työtapaturmat ja koettu työperäinen sairastavuus [Work accidents and perceived work-related diseases]. In: Paananen S, editor. Työn vaarat: koetut työperäiset sairaudet, työtapaturmat ja työväkivaltatapaukset [Hazards of work: perceived diseases, work accidents ja acts of violence]. Helsinki: Tilastokeskus; 2000. Työmarkkinat 2000:15.

22. Julkunen R, Kalliomäki-Levanto T, editors. Määräaikaisten ja tilapäisten työsuhteiden vaikutukset yksilön hyvinvointiin ja työyhteisön toimintaan: raportti Työsuojelurahastolle [The effects of fixed-term and temporary employment relationships on the well-being of an individual and the functioning of a work community: report for the Occupational and Health and Safety Fund]. Helsinki: Työterveyslaitos, Psykologian osasto; 1998.

23. Julkunen R, Nätti J. Muuttuvat työajat ja työsuhteet: työministeriön työaikamuotojen tutkimus- ja kehittämisprojektin ensimmäinen vaihe [Changing working hours and employment relationships: first phase of the research and development project on types of work time of the Finnish Ministry of Labour]. Helsinki: Työministeriö, 1995. Työpoliittinen tutkimus 104.

24. Nätti J. Temporary employment in the Nordic countries: a trap or a bridge. Work Employment Soc. 1993;3:451-64.

25. Nätti J, Kinnunen U, Mäkinen P, Loikkanen E, Mauno S, Virolainen M. Työn epävarmuus ja hyvinvointi [Work insecurity and well-being]. Jyväskylä: Jyväskylän yliopisto; 1995. Jyväskylän yliopiston yhteiskuntapolitiikan papereita, 92.

26. Happonen M, Mauno S, Nätti J, Kinnunen U. Koettu työn epävarmuus: pitkittäistutkimus kolmessa organisaatiossa [Perceived work insecurity: a longitudinal study in three organizations]. Janus. 1998;6(3):279-98.

27. Virtanen P, Kivimäki, M, Ferrie JE, Elovainio M, Honkonen $\mathrm{T}$, Pentti J, et al. Temporary employment and antidepressant medication: a register linkage study. J Psychiatr Res. 2008;42(3):221-9. Epub 2007 Jan 22 [PubMed - as supplied by publisher]. Cited 24 October 2007.

28. Kivimäki M, Vahtera J, Thomson L, Griffits A, Cox T, Pentti J. Psychosocial factors predicting employee sickness absence 
during economic decline. J Appl Psychol. 1997;82:858-72.

29. Kivimäki M, Vahtera J, Virtanen M, Elovainio M, Pentti J, Ferrie, JE. Temporary employment and risk of overall and causespecific mortality. Am J Epidemiol. 2003;158(7):663-8.

30. Virtanen M, Kivimäki, M, Elovainio M, Vahtera J. Selection from fixed term to permanent employment: prospective study on heath, job satisfaction, and behavioural risks. J Epidemiol Community Health. 2002;56:693-9.

31. Virtanen P, Vahtera J, Kivimäki M, Liukkonen V, Ferrie J. Labor market trajectories and health: a four-year follow-up study of initially fixed-term employees. Am J Epidemiol. 2005;161(9):840-6.

32. Sutela H. Fixed-term contracts still common in public sector [Internet]. Luxembourg: European Foundation for the Improvement of Living and Working Conditions; 2006 [cited 1 May 2008]. Available from: http://www.eurofound.europa. eu/ewco/2006/04/FI0604NU04.htm.

33. Ministry of Finance. Aging a major challenge to sustainable general government financing: Government gives Prime Minister's statement to Parliament on Stability Programme Update [press release, Internet]. Helsinki: Ministry of Finance; 2007/127 [cited 1 May 2008]. Available from: http://www. vm.fi/vm/en/03_press_releases_and_speeches/01_press_ releases/20071129Ageing/name.jsp.

34. Nurminen MM, Heathcote CR, Davis BA, Puza BD. The looming labour force shortage in Finland. In: International Statistical Institute, editor. Proceedings of the 55th Session of the International Statistical Institute (ISI 2005) [CD-ROM]. Sydney: International Statistical Institute; 2006.

35. Työvoimapula pahenee pian Helsingin seudulla [Labour force shortage worsens in the Helsinki area]. Helsingin Sanomat. 2007 June 17.

36. Käsi ylös, kuka lähtee suomeen? [Hand up, who will leave for Finland?]. Helsingin Sanomat. 2008 January 20.

37. Pohjoisen hiihtokeskuksissa kova työvoimapula sesongin alla [Hard labour shortage in Northern ski centers before the season]. Helsingin Sanomat. 2008 January 20.

38. Remery C, Henkens K, Schippers J, Ekamper P. Managing an aging workforce and a tight labour market: view held by Dutch employers. Popul Res Policy Rev. 2003;22:21-40.

39. The European Industrial Relations Observatory (EIRO) New legislation on fixed-term and part-time work in force. Luxembourg: The European Industrial Relations Observatory (EIRO); 2003. Available from: http://www.eurofound.europa. eu/eiro/2003/08/feature/hu0308101f.htm.

40. Ylikorkala A, Hakonen A, Hulkko K. Tulospalkkauksesta toivoa toiminnan kehittämiseen: kokemuksia tulospalkkauksesta ja sen kehittämisestä terveydenhuollon yksiköissä vuosina 2000-2003 [From performance promotion to developing organization: experiences of performance promotion and developing it in health care units in 2000-2003]. Helsinki: Työministeriö; 2005. TYKES [Työelämän kehittämisohjelma] raportteja, 41.

41. Saloniemi A, Virtanen P, Vahtera J. The work environment in fixed-term jobs: are poor psychosocial conditions inevitable. Work Employment Soc. 1993;18(1):193-208.

42. Koistinen, P. Työpolitiikan perusteet [The foundations of labour policy]. Helsinki: WSOY; 1993.

43. Parjanne M-L. Määräaikaiset työntekijät-joustava työvoimapuskuri [Fixed-term employees-a flexible labour force buffer]. Helsinki: Ministry of Labour; 1998. Työpoliittinen Aikakauskirja 2.

44. Waite M, Will L. Fixed-term employees in Australia: incidence and characteristics. Melbourne: AustInfo, 2002. Productivity Commission Staff Research Paper [cited 1 May 2008]. Available from: http://ssrn.com/abstract=304306.

45. Buchanan J. Paradoxes of significance: Australian casualisation and labour productivity. In: University of Sydney, editor. Proceedings of work interrupted: ACTU casuals and insecure employment conference: 2 August 2004, Melbourne. Sydney: University of Sydney. Australian Centre for Industrial Relations Research and Training (ACIRRT); 2004. ACIRRT Working Paper 93.

Received for publication: 4 September 2007 


\section{Appendix}

\section{Numerical estimates of worklife expectancies for Finnish women and men.}

Table 1. Women's future worklife expectancies for two states of employment (1="employed, permanent" and 2 = "employed, fixed term") for quincennial ages, 15-60 years, and for the 10-year period 1997-2006. For states 3 ("other alive") and 4 ("dead"), figures are shown only for ages 25 and 55 years.

\begin{tabular}{|c|c|c|c|c|c|c|c|c|c|c|}
\hline \multirow[t]{2}{*}{ Age $(x)$} & \multicolumn{10}{|c|}{ Year $(t)$} \\
\hline & 1997 & 1998 & 1999 & 2000 & 2001 & 2002 & 2003 & 2004 & 2005 & 2006 \\
\hline \multicolumn{11}{|l|}{15 years } \\
\hline State (j) 1 employed, permanent & 20.61 & 21.14 & 21.72 & 21.85 & 22.55 & 22.91 & 23.24 & 23.45 & 23.84 & 23.64 \\
\hline State (j) 2 employed, fixed-term & 5.75 & 5.78 & 5.86 & 5.95 & 6.08 & 6.19 & 6.27 & 6.30 & 6.41 & 6.52 \\
\hline \multicolumn{11}{|l|}{20 years } \\
\hline State (j) 1 employed, permanent & 20.11 & 20.54 & 21.09 & 21.21 & 21.89 & 22.19 & 22.51 & 22.72 & 23.10 & 22.95 \\
\hline State $(j) 2$ employed, fixed-term & 5.03 & 5.06 & 5.13 & 5.20 & 5.30 & 5.39 & 5.45 & 5.46 & 5.54 & 5.61 \\
\hline \multicolumn{11}{|l|}{25 years } \\
\hline State (J) 1 employed, permanent & 19.07 & 19.43 & 19.94 & 20.04 & 20.70 & 20.93 & 21.24 & 21.44 & 21.79 & 21.66 \\
\hline State (j) 2 employed, fixed-term & 4.05 & 4.09 & 4.14 & 4.19 & 4.25 & 4.32 & 4.36 & 4.36 & 4.41 & 4.46 \\
\hline State (j) 3 other alive & 16.30 & 15.91 & 15.35 & 15.20 & 14.49 & 14.18 & 13.84 & 13.63 & 13.23 & 13.32 \\
\hline State $(j) 4$ dead & 0.57 & 0.57 & 0.57 & 0.57 & 0.57 & 0.57 & 0.57 & 0.57 & 0.57 & 0.57 \\
\hline \multicolumn{11}{|l|}{30 years } \\
\hline State (J) 1 employed, permanent & 17.37 & 17.65 & 18.13 & 18.20 & 18.83 & 19.02 & 19.30 & 19.47 & 19.80 & 19.65 \\
\hline State (j) 2 employed, fixed-term & 3.03 & 3.06 & 3.09 & 3.13 & 3.15 & 3.21 & 3.23 & 3.23 & 3.26 & 3.30 \\
\hline \multicolumn{11}{|l|}{35 years } \\
\hline State (J) 1 employed, permanent & 14.99 & 15.23 & 15.67 & 15.70 & 16.30 & 16.45 & 16.70 & 16.84 & 17.14 & 16.97 \\
\hline State (j) 2 employed, fixed-term & 2.14 & 2.16 & 2.17 & 2.21 & 2.21 & 2.25 & 2.26 & 2.27 & 2.28 & 2.33 \\
\hline \multicolumn{11}{|l|}{40 years } \\
\hline State $(J) 1$ employed, permanent & 12.11 & 12.30 & 12.69 & 12.70 & 13.24 & 13.35 & 13.57 & 13.69 & 13.96 & 13.79 \\
\hline State (j) 2 employed, fixed-term & 1.45 & 1.46 & 1.47 & 1.15 & 1.49 & 1.52 & 1.53 & 1.54 & 1.55 & 1.59 \\
\hline \multicolumn{11}{|l|}{45 years } \\
\hline State (J) 1 employed, permanent & 8.95 & 9.09 & 9.42 & 9.42 & 9.88 & 9.94 & 10.13 & 10.26 & 10.48 & 10.34 \\
\hline State (j) 2 employed, fixed-term & 0.94 & 0.95 & 0.95 & 0.98 & 0.97 & 1.01 & 1.01 & 1.01 & 1.02 & 1.05 \\
\hline \multicolumn{11}{|l|}{50 years } \\
\hline State (j) 1 employed, permanent & 5.80 & 5.88 & 6.13 & 6.13 & 6.48 & 6.49 & 6.66 & 6.78 & 6.96 & 6.86 \\
\hline State (J) 2 employed, fixed-term & 0.56 & 0.58 & 0.58 & 0.60 & 0.60 & 0.63 & 0.63 & 0.63 & 0.63 & 0.65 \\
\hline \multicolumn{11}{|l|}{55 years } \\
\hline State (j) 1 employed, permanent & 3.00 & 3.02 & 3.18 & 3.17 & 3.41 & 3.37 & 3.49 & 3.60 & 3.72 & 3.68 \\
\hline State (J) 2 employed, fixed-term & 0.29 & 0.30 & 0.31 & 0.32 & 0.32 & 0.35 & 0.35 & 0.34 & 0.35 & 0.35 \\
\hline State ( $) 3$ other alive & 6.20 & 6.17 & 6.00 & 6.00 & 5.76 & 5.76 & 5.64 & 5.54 & 5.42 & 5.46 \\
\hline State $(J) 4$ dead & 0.51 & 0.51 & 0.51 & 0.51 & 0.51 & 0.52 & 0.51 & 0.52 & 0.52 & 0.52 \\
\hline \multicolumn{11}{|l|}{60 years } \\
\hline State (j) 1 employed, permanent & 0.97 & 0.95 & 1.01 & 1.01 & 1.10 & 1.06 & 1.12 & 1.19 & 1.24 & 1.24 \\
\hline State (J) 2 employed, fixed-term & 0.10 & 0.11 & 0.11 & 0.11 & 0.12 & 0.13 & 0.13 & 0.13 & 0.13 & 0.13 \\
\hline
\end{tabular}


Table 2. Men's future worklife expectancies for two states of employment ( $1=$ "employed, permanent" and 2 = "employed, fixed term") for quincennial ages, 15-60 years, and for the 10-year period 1997-2006. For states 3 ("other alive") and 4 ("dead"), figures are shown only for ages 25 and 55 years.

\begin{tabular}{|c|c|c|c|c|c|c|c|c|c|c|}
\hline \multirow[t]{2}{*}{ Age $(x)$} & \multicolumn{10}{|c|}{ Year $(t)$} \\
\hline & 1997 & 1998 & 1999 & 2000 & 2001 & 2002 & 2003 & 2004 & 2005 & 2006 \\
\hline \multicolumn{11}{|l|}{15 years } \\
\hline State (J) 1 employed, permanent & 21.88 & 22.44 & 23.05 & 23.17 & 23.93 & 24.35 & 24.68 & 24.83 & 25.26 & 24.99 \\
\hline State $(j) 2$ employed, fixed-term & 4.04 & 4.03 & 3.97 & 3.99 & 3.87 & 3.82 & 3.80 & 3.85 & 3.80 & 3.87 \\
\hline \multicolumn{11}{|l|}{20 years } \\
\hline State (J) 1 employed, permanent & 21.39 & 21.92 & 22.50 & 22.63 & 23.35 & 23.76 & 24.07 & 24.20 & 24.61 & 24.35 \\
\hline State (j) 2 employed, fixed-term & 3.43 & 3.39 & 3.34 & 3.34 & 3.25 & 3.20 & 3.18 & 3.20 & 3.16 & 3.21 \\
\hline \multicolumn{11}{|l|}{25 years } \\
\hline State $(J) 1$ employed, permanent & 19.99 & 20.46 & 21.00 & 21.09 & 21.77 & 22.14 & 22.41 & 22.51 & 22.89 & 22.65 \\
\hline State (J) 2 employed, fixed-term & 2.57 & 2.53 & 2.49 & 2.48 & 2.42 & 2.37 & 2.36 & 2.36 & 2.33 & 2.36 \\
\hline State $(j) 3$ other alive & 16.77 & 16.34 & 15.85 & 15.76 & 15.16 & 14.84 & 14.58 & 14.47 & 14.13 & 14.34 \\
\hline State $(J) 4$ dead & 0.67 & 0.68 & 0.68 & 0.66 & 0.66 & 0.65 & 0.65 & 0.65 & 0.65 & 0.65 \\
\hline \multicolumn{11}{|l|}{30 years } \\
\hline State (J) 1 employed, permanent & 17.59 & 18.01 & 18.48 & 18.55 & 19.15 & 19.48 & 19.72 & 19.80 & 20.12 & 19.90 \\
\hline State (J) 2 employed, fixed-term & 1.80 & 1.77 & 1.75 & 1.74 & 1.70 & 1.67 & 1.66 & 1.66 & 1.63 & 1.64 \\
\hline \multicolumn{11}{|l|}{35 years } \\
\hline State (J) 1 employed, permanent & 14.54 & 14.90 & 15.31 & 15.36 & 15.90 & 16.17 & 16.38 & 16.45 & 16.73 & 16.52 \\
\hline State (J) 2 employed, fixed-term & 1.24 & 1.22 & 1.21 & 1.20 & 1.19 & 1.17 & 1.16 & 1.15 & 1.14 & 1.14 \\
\hline \multicolumn{11}{|l|}{40 years } \\
\hline State ( () 1 employed, permanent & 11.21 & 11.52 & 11.87 & 11.91 & 12.37 & 12.60 & 12.78 & 12.84 & 13.08 & 12.88 \\
\hline State (J) 2 employed, fixed-term & 0.85 & 0.84 & 0.84 & 0.83 & 0.83 & 0.82 & 0.82 & 0.81 & 0.81 & 0.79 \\
\hline \multicolumn{11}{|l|}{45 years } \\
\hline State $(J) 1$ employed, permanent & 7.92 & 8.18 & 8.47 & 8.50 & 8.88 & 9.06 & 9.21 & 9.26 & 9.46 & 9.28 \\
\hline State $(\jmath) 2$ employed, fixed-term & 0.58 & 0.58 & 0.58 & 0.57 & 0.58 & 0.57 & 0.57 & 0.57 & 0.56 & 0.55 \\
\hline \multicolumn{11}{|l|}{50 years } \\
\hline State (J) 1 employed, permanent & 4.97 & 5.16 & 5.39 & 5.40 & 5.69 & 5.82 & 5.93 & 5.98 & 6.13 & 5.97 \\
\hline State $(\jmath) 2$ employed, fixed-term & 0.38 & 0.38 & 0.38 & 0.38 & 0.39 & 0.38 & 0.38 & 0.38 & 0.38 & 0.37 \\
\hline \multicolumn{11}{|l|}{55 years } \\
\hline State $(J) 1$ employed, permanent & 2.61 & 2.73 & 2.88 & 2.87 & 3.06 & 3.13 & 3.20 & 3.24 & 3.34 & 3.23 \\
\hline State $(j) 2$ employed, fixed-term & 0.22 & 0.22 & 0.23 & 0.22 & 0.26 & 0.23 & 0.23 & 0.23 & 0.23 & 0.22 \\
\hline State $(\jmath) 3$ other alive & 6.64 & 6.51 & 6.36 & 6.37 & 6.17 & 6.11 & 6.03 & 5.99 & 5.90 & 6.02 \\
\hline State $(\jmath) 4$ dead & 0.53 & 0.53 & 0.53 & 0.53 & 0.53 & 0.53 & 0.53 & 0.53 & 0.53 & 0.53 \\
\hline \multicolumn{11}{|l|}{60 years } \\
\hline State $(J) 1$ employed, permanent & 0.95 & 1.00 & 1.07 & 1.06 & 1.14 & 1.16 & 1.20 & 1.22 & 1.26 & 1.21 \\
\hline State $(j) 2$ employed, fixed-term & 0.10 & 0.10 & 0.10 & 0.10 & 0.10 & 0.10 & 0.10 & 0.10 & 0.10 & 0.10 \\
\hline
\end{tabular}

